\title{
The Linguo-Cultural Concept TORSCHLUSSPANIK as the Representative of Ethno-Specific Psycho-Emotional State of Germans
}

\section{Лінгвокультурний концепт TORSCHLUSSPANIK як репрезентант етноспецифічного психоемоційного стану німців}

Kostiantyn Mizin

Dr. in Philology,

Professor
Костянтин Мізін

доктор філологічних наук, професор

\author{
E-mail: kmizin@i.ua \\ orcid.org/0000-0003-4449-0067 \\ Researcher ID: C-3943-2019 \\ Scopus ID: 57195981991
}

\section{Liubov Letiucha}

Ph.D. in Philology, Associate

Professor
Любов Летюча

кандидат філологічних наук, доцент

E-mail: 1etinna@ukr.net

orcid.org/0000-0002-0481-850X

Pereiaslav-Khmelnytskyi

Hryhorii Skovoroda State

Pedagogical University

$\triangle$ 30, Sukhomlynskyi Str.,

Pereiaslav-Khmelnytskyi,

Kyiv Reg., Ukraine, 08401
ДВНЗ «Переяслав-

Хмельницький державний педагогічний університет імені Григорія Сковороди»

$\checkmark$ вул. Сухомлинського, 30, м. Переяслав-Хмельницький, Київська обл., Україна, 08401

Original manuscript received July 22, 2018

Revised manuscript accepted March 12, 2019 
The Linguo-Cultural Concept TORSCHLUSSPANIK as the Representative...

\section{ABSTRACT}

The given article studies linguo-specificity of the German linguo-cultural concept TORSCHLUSSPANIK that covers a wide semantic space of human psycho-emotional state, which is concentrated around the semantic center "midlife crisis». The revelation of the semantic content of this concept is conducted by verifying the methodology which is a sequence of research procedures. The scientific reliability of this methodology is ensured by Corpus Linguistics data to empirically reinforce linguistic methods proper. Procedure steps of the given methodology are used to identify crosslanguage equivalents of the concepts names in the comparative linguo-cultural studies in general, because cross-language equivalence allows studying semantic equivalence within the corresponding conceptual world pictures (CWP) which makes it possible to reveal specific vs. unique senses of the compared concepts.

The conducted analysis proves that the reproduction of the fragment in the German CWP representing the concept TORSCHLUSSPANIK is possible in Ukrainian only with the help of actualizing sense equivalents of the given concept - FEAR, MIDDLE AGE, AGING, TIME, LIFE and DEATH. This way their symbolic and mythological meanings are specifically actualized. It was determined in the article, that ethnospecificity of the concept TORSCHLUSSPANIK arose due to the particular combination of meanings that represent a wide emotional palette of Germans, for whom psychoemotional depressive state of "midlife crisis» is reinforced by the emotion of fear. In its turn, the latter is intensified by the emotion of disappointment at being late, not realising smth, failing to do smth etc. It is remarkable that disappointment is usually accompanied by anger, anxiety, guilt, hostility, malevolence, envy, jealousy and shame.

Key words: emotion, psycho-emotional state, linguo-cultural concept, Linguoculturology, middle age, fear, disappointment.

\section{Introduction}

Cognition is known to be the main notion of cognitive sciences, in particular of Cognitive Linguistics, which has been exposed to various transformations within the period of 30 years over the postSoviet linguistic space and has created new linguo-cognitive trends. The latter ones are intended to reveal the correlation between the human cognition reflected in the language (speech) on the one hand and culture (society) on the other in as much detail as possible. A significant role in cognitive processes is played by emotions, which have been neglected by cognitologists for a long period of time. As a result emotional factors still remain outside many cognitive linguistic theories and psycho-linguistic models. The reasons are to be found in the traditional differentiation between cognitive and emotional spheres. However, 
nowadays the situation is significantly changing: it has been proved at the experimental level that cognitive processes are influenced to a great extent by emotional factors (see, i.e: Domasio, 2000; Krumhansl, 2002; Phelps, 2006; Roth, 2003). That is why most of psychological theories consider emotions as an integral part of cognitive states and processes (see, i.e: Dalgleich \& Power, 1999; Reisenzein, 2019), which, actually cannot be otherwise, for emotions are defined as mental systems of knowledge and evaluation (see, i.e: Schwarz-Friesel, 2007). This creates methodological grounds for studies of emotions from the perspective of the mental constructs, which are used as analytical instruments in the framework of Cognitive-Oriented Linguistics. In the article such mental construct is represented by a linguo-cultural concept while the German concept «Torschlusspanik» is the unexplored emotional state.

We should preliminary note that Cognitive Linguistics vs. Linguocognitology expansion into the post-Soviet linguistic space created methodological grounds for the appearance of a number of typically post-Soviet linguistic disciplines, among them Linguoculturology and Linguoconceptology. These disciplines resulted from certain methodological transformations to which progressive ideas of American and Western European linguo-cognitologists were exposed at the end of 20th century during their adaptation to linguo-philosophical traditions of Soviet Linguistics (Mizin, 2017c: 13-14). Only at first glance was the latter positivism-oriented and structuralism-limited, as a matter of fact, it largely tended to different culturological ideas, to neo-humboldtianism in particular. Here we should mention such typically Soviet linguo-didactic subjects as Culturology and culture-oriented linguistic studies, culturebased theories in the framework of Soviet and post-Soviet Phraseology, and also Ethnolinguistics which is noticeably different from its American counterpart in theoretical and philosophical foundations.

In our opinion, Linguoconceptology is a methodological «twin» of Linguoculturology - one of the central directions in modern Linguistics in Ukraine. The only significant difference about them, if any, lies in the fact that we can only see that Linguoculturology, unlike Linguoconceptology, has wider epistemological tools as the latter is limited by linguo-cultural concepts studies. However, the term «linguocultural concept» is also a product of post-cultural theories in post-Soviet Linguistics, since the given concept is not just a mental construct vs. cognitive structure that serves for perception, accumulation and 
transmission of information in human mental space (Schwarz, 1992: 84), but also a culture «cluster» in human consciousness (Stepanov, 2004: 42-67). As we can see, there is a clear adaptation of Western European concept understanding, where the latter is viewed as an operating unit of information (a memory construct), to the Soviet and post-Soviet theoretical and philosophical traditions where the operating nature of the concept acquired additional cultural parameters (concepts create a conceptual sphere which contains a nation's culture in a considered form (Lihachev, 1993)). Thus, according to the modern interpretation concepts are considered to be complex (there are at least three components notional, perceptual and evaluative) units of human mental activity (thinking and memory) which reflect and express the culture.

Therefore, it is important for linguo-cultural studies to reconstruct, with the help of language, the fragment of the conceptual world picture (CWP) where the universal cognitive (psycho-mental) and receptive (psycho-physiological) mechanisms and constructs forming the picture, «overlap» with specific linguo-cultural and ethno-cultural factors. These factors lead to a specific world perception, understanding and behaviour of a definite national community representatives, in the process of ethno- and socio-cultural development of speakers.

This reconstruction causes some criticism from opponents of Linguoculturology who believe that language and thought as unrelated phenomena cannot influence each other in the process of world categorization, conceptualization and verbalization. A particularly sharp criticism is directed at Sapir-Whorf hypothesis, which to a great extent forms theoretical and methodological foundations for Linguoculturology, and some neo-humboldtian ideas. Linguoculturology opponents even believe that the latter's methodological tools are unscientific (for details see: Mizin, 2017b). For this reason, the followers of linguo-cultural studies in Linguistics are permanently searching for new methodological ideas to strengthen empirical component of methodology in linguoculturological works.

The purpose of this article is to verify methodology that can be used to identify linguo-specificity of the name of the German linguocultural concept TORSCHLUSSPANIK, which hasn't been the object of linguo-culturological study so far. The scientific reliability of this methodology is guaranteed by the usage of Corpus Linguistics data. It empirically reinforces linguistic methods proper (primarily 
etymological, definitional and context analysis) which make it possible to identify cross-language equivalents of the names for the compared concepts. Cross-language equivalence allows studying semantic equivalence within the corresponding CWP. That makes it possible to reveal specific vs. unique senses of the analysed concepts.

\section{Research Methods}

The results of the methods applied in our previous works, devoted to identifying linguo-specific nature of names of the German linguo-cultural concepts SCHADENFREUDE, FERNWEH, GÖNNEN, KUMMERSPECK etc. (see, i.e.: Mizin, 2017a), have demonstrated its verification potential, especially in the cases where researchers' conclusions on linguo-specificity are based on the auto- or heterostereotypies, but not on objective linguistic analysis which can put researchers on the wrong track i.e. make them look for linguospecificity of language units which does not actually exist. To avoid wrong conclusions and biased results in linguo-cultural studies which uses the mental construct - linguo-cultural concept as the main epistemic unit, during the first stage of concept analysis a researcher should (1) analyse extra-lingual information about the concept to define its linguo-cultural relevance, (2) involve a number of procedures from traditional linguistic methods (etymological, definitional and contextual analyses) and (3) enhance the empirical component of research using Corpus Linguistics data (statistics, language corpora etc.).

The above research steps form the basis of the methodology, whose adequacy verification is tested on the basis of the concepts having linguo-specific names. However, in future we are planning to use it to examine universal concepts which don't seem to possess any specificity. Untranslatability vs. hard-translatability is believed to be a distinctive feature of linguo-specific units (Zaliznjak, 2016: 841). That is why identifying various semantic connotations of concept names for which no equivalent can be found in another language or those that cannot be neutralized in translation is an important component of this methodology. Translation analysis allows us to (1) identify language counterparts or «functionally equivalent fragments» (Dobrovol'skij, Kretov \& Sharov, 2005) in the cases where an original concept name in 
the object linguo-culture is lacunar, and (2) find concept-correlates while analysing contrastive features of ethno-unique concepts. The latter aspect allows us to define the boundaries of the CWP fragment in the target linguo-culture which at least to some extent covers meanings similar to concept in the original linguo-culture. This approach is especially important for the studies where contrastive or translational analysis aims to study cross-cultural transfer of ethno-specific and ethno-unique concepts (concept transfer). It is obvious that translation cannot provide a full concept transfer i.e. to transfer all its senses to a «foreign» CWP is practically an impossible task, but it is quite possible to bring an idea of the «foreign» fragment of this picture to recipients.

Thus, studying cross-cultural semantic equivalence involves identifying cross-language equivalence. But definitional and etymological analyses do not make it possible to find an equivalent language unit in the cases when a word's codified meaning as well as its etymology are simply not available. In this particular case it is possible to rely on language corpus digital database that can provide examples of how a word is used in different types of discourse. By translating these samples into the target language vs. target languages we can define cross-language equivalent vs. cross-language equivalents.

It should be noted that the new prospects in studying crosslanguage equivalence emerged with the appearance of parallel texts corpora (Dobrovol'skij, 2006; Dobrovol'skij, 2015; Sichinava, 2014). Developers of automated over-corpus database believe that contrastive corpus studies are much more effective if database is «built upon» parallel corpus which enables one to find equivalents of language units that, first, are «certified» i.e. have real output data, and, secondly, they are marked in many ways i.e. they have different quantitative and qualitative data. The most important point, directly related to the analysed problem, is that in over-corpus database each language unit used in the text of the translation is provided with its functionally-equivalent fragment (FEF). The latter represents at the verbal level (target language) the fragment of CWP (target linguo-culture) transferred from the source linguo-culture as a result of translation as a cognitive process.

Unfortunately, parallel texts corpora and over-corpus database in particular are only found in some language corpora. For example, there are no German-Ukrainian or Ukrainian-German parallel texts corpora because there is no Ukrainian corpus more or less correlative in volume 
to other European languages. For instance, «Ukrainian national linguistic corpus» (UNLC) is actually inaccessible to an average Ukrainian user, while «Ukrainian language corpus» on the website «Linguistic portal» (KUM) is currently being developed. This contributes to both increase in its volume in general and technical capacities improvement for working with the corpus digital database. However, the volume of «Ukrainian language corpus» is not sufficient enough to complete thorough contrastive studies, so there is not much to say about over-corpus database.

It is noteworthy that over-corpus database automatic procedures make it possible to distinguish typical features that indicate probable linguo-specificity of a word (Zaliznjak, 2016: 846-847). In the analysis of ethno-specific and ethno-unique concepts when the target translation languages do not contain either a one-word equivalent for a certain concept name or language counterparts in general, the most common are the following features: 1) the presence of numerous FEF; 2) the presence of multi-component FEF; 3) cases where the word is not translated at all i.e. FEF is missing. These same features or criteria of words' linguo-specificity are crucial for our study where we examine linguo-specificity «mechanically» (author's translation of discursive samples) because there are no English-Ukrainian digital corpora of parallel texts. However, the use of «mechanical» analysis does not mean that the results and conclusions of the proposed research are scientifically unreliable or questionable: even the developers of over-corpus database of parallel cross-language corpora state that quantitative methods for measuring linguo-specificity can only be effective in combination with semantic analysis methods proper (Zaliznjak, 2016: 850), where «digital» procedures are closely combined with the «mechanical» ones.

\section{Results and Discussion}

Name lacunarity (at least in European languages) of the concept TORSCHLUSSPANIK testifies to its ethno-unique nature. In this case, one should (1) find at least approximate equivalents in other language vs. other languages at the verbal level, and (2) at the level of consciousness - to identify semantic correlates presenting a corresponding fragment of CWP in the target linguo-culture vs. target 
linguo-cultures. In the proposed study with the Ukrainian linguo-culture being the target one the given concept is absolutely «unfamiliar» to its representatives.

To determine the semantic content of the concept TORSCHLUSSPANIK, it is methodologically correct to use translation analysis of discursive samples containing the name of the concept from German into Ukrainian. For this reason, we use digital corpus of texts (DWDS) (the word-form Torschlusspanik is most frequently found in the newspaper sub-corpus - 384 uses). When translating discursive samples we should take into account etymological, historical and cultural, and mythological foundation of the lexeme Torschlusspanik motivation:

1) there is no etymological data about this lexeme;

2) historical and etymological foundation of the word is not entirely clear either. The emergence of the word is related to the tradition of keeping gates closed at night in the cities surrounded by a protective wall. In this way the city citizens were protected at night but those who came after the closure of the gate had to pay rent for a single entry that townspeople found quite annoying. This fact, as it is shown below, underlay the core meaning of the lexeme Torschlusspanik - 'fear of being late';

3) in Germanic as well as in Slavic mythology, gates denote a boundary between life and death. Ancient Roman and Greek mythology also prove this. Thus, a fear / panic of closing gates can mean a fear or panic of the transience of life and the inevitability of death i.e. closing gates implies the impending death. Consequently, a person has a fear (panic) that life will soon be over and there is less and less time to fulfil some plans / ideas / perspectives.

Below are given the most relevant examples which were used to determine the meaning of the lexeme Torschlusspanik:

(1) Fans des Sommerwetters müssten also keine "Torschlusspanik» entwickeln, sagte der Meteorologe // Отже, за словами метеоролога, любителям літньої погоди не слід панікувати, що літній сезон може скоро закінчитися;

(2) Die SPD sei angesichts der Umfragewerte anscheinend in Torschlusspanik // 3 огляду на результати опитувань СДПН, здається, лихоманить із-за втрати можливостей через брак часу;

(3) Dies kann eine übersteigerte Erfolgserwartung an sich selbst sein, eine nicht erfüllbare Erwartung an den potentiellen Partner oder 
so etwas wie Torschlusspanik // Це може бути завищене очікування успіху самим собою, реальне очікування потенційного партнера або чогось подібного на киталт «кризи середнього віку", тобто паніки або страху через те, щи людині все жс не вдається знайти гідного партнера для илюбу, сім'ї, сумісного жсиття, народжсння дітей, а репродуктивний період скоро закінчується;

(4) Während alle um ihn herum vom Reihenhäuschen träumen und seine Freundin vom Kinderkriegen, flüchtet der Brauereiangestellte $<\ldots>$ in Torschlusspanik nach Argentinien $<\ldots>$ // У той момент як усі навколо нього мріють про зблокований житловий будиночок, а його подруга - про народження дитини, працівник броварні [...] тікає через страх, викликаний кризою середнього віку, до Аргентини [...];

(5) Denn die Torschlusspanik der Mittdreißiger $<\ldots>$ ist nur allzu bekannt: die Ahnung, dass die Zeit abläuft, fürs Kinderkriegen, für die Karriere // Тому щзо "Torschlusspanik» тридиятип'ятирічних, тобто страх, що жсиття швидко проходить, [...] є досконально відомим: відчуття, щуо час для народження дітей, для кар'єри спливає;

(6) Die handelsübliche Arbeitszeit für ein Buch beträgt zwar ein ganzes Jahr, aber wir überspringen die Hälfte des Jahres <...> und steigen direkt in die Torschlusspanik ein // Попри те, щуо час роботи над книгою складає за стандартними мірками цілий рік, ми перестрибуємо півроку [...] i втраплясмо прямо у стан паніки, яка викликана тим, що часу вже зовсім не залишається;

(7) Wenn seine Analyse richtig sein sollte, so wird eine "Torschlusspanik» an den Rentenmärkten die Kurse nach oben treiben und die Renditen fallen lassen // Якщзо його аналіз виявиться правильним, то "Torschlusspanik», тобто паніка через брак часу, спровокує стрімкий ріст курсів на ринках иінних паперів із твердим відсотком та падіння доходів;

(8) Die Eile, mit der die CDU jetzt vorgeht und die FDP unter Druck setzt, halte ich für eine Art Torschlusspanik der konservativen Hardliner // Поспіх, з яким ХДС виходить тепер уперед $і$ здійснює тиск на вільних демократів (ВДП), я вважаю одним із видів паніки через цейтнот консервативних противників компромісів;

(9) Da wir (sie ist auch 35) beide keine Kinder wollen, war das Thema "Torschlußpanik» also auch eher keines // Оскільки ми 
The Linguo-Cultural Concept TORSCHLUSSPANIK as the Representative...

(ій також 35 років) обоє не хотіли дітей, то «криза середнього віку" в иьому питанні була майже відсутньою;

(10) Sie will einen Mann fürs Leben und bekommt deswegen langsam Torschlusspanik, allerdings wollen sämtliche Verwandten und Bekannten sie mit irgendwem verkuppeln, was also ziemlich schiefläuft // Вона хоче чоловіка для життя і тому іï повільно охоплюе паніка, викликана кризою середнього віку, та численні родичі й знайомі хочуть ї̈ з ким-небудь пов'язати, щзо, власне, не зовсім вдається;

(11) In diesem Ratgeber-Artikel geben wir Ihnen Tipps, wie Sie Torschlusspanik in der Partnersuche vermeiden und dennoch rechtzeitig den Traumpartner finden // У иій статті ми надамо Вам поради, як уникнути страху через зрілий вік при пошуку партнера та як, усе ж таки, вчасно знайти партнера Вашої мрї;

(12) Sony macht hier einen auf Torschlusspanik, weil man Microsoft nicht wieder den ersten Schuss überlassen will // «Sony» виготовила $\dddot{i} *$ тут через панічний страх не втратити час, бо не хочеться знову віддати «Microsoft» пальму першості.

*Sony PlayStation 3

Our translation proves that all three above mentioned linguospecific features are typical of the lexeme Torschlusspanik:

1) the lexeme is translated differently in most cases (there is a great number of FEF), e.g.: (2), (3), (4), (5) (11) (12);

2 ) at times it is only possible to render the meaning of the lexeme through a complex sentence (multi-component FEF), e.g.: (1), (2), (3), (4), (5), (6);

3) there are instances where the word is not translated (FEF missing), e.g.: (1), (8).

The lexemes fear (cmpax) and panic (паніка) in the Ukrainian translation are practically interchangeable because panic is nothing but a state of intense fear. The fear itself in the word Torschlusspanik is mainly related to the process of rapid aging and approaching death.

It is noteworthy that the Germans themselves can use quotation marks for the word, underlining originality of the notion it nominates e.g.: (1), (5), (7). Integral semantics the lexeme conveys is 'a fear (panic) of being late' and 'a fear (panic) of not making it on time' but its basic semantic shades are: 
a) 'a fear (panic) caused by lack of time', e.g.: (2) (7) (12);

b) 'a fear (panic) brought about by transience of time', e.g.: (1), (5);

c) 'midlife crisis' that is 'a fear of loneliness resulted from rapid aging (which often leads to casual and fleeting relationships)', e.g.: (3), (4), (9), (10) (11);

d) 'a fear (panic) of being unable to realize some life / career plans because of mature age' (6), (8).

As we can see, the lexeme Torschlusspanik contains the meaning that is conventionally divided into two semantic vectors: (a) a fear of being late related to time and (b) a fear of failing to realize different life plans (marriage, having children, career, etc.). However, it is impossible to determine which of the semantics is primary. We can assume that the primary is the meaning conveying the situation where a middle-aged person has a panic fear of rapid aging. This fear is considerably intensified when one needs time to have a family (finding a partner) and have children (women's physiological age deadlines for childbearing). First fixations of the analysed lexeme prove this idea. Thus, one of the stories by Lola (Aloisia) Kirschner, better known in the early 20th century under the name of Ossip Shubin, written in 1892, is called «Torschlusspanik» (Brümmer, 1913). The phrase Midlife crisis conveys this meaning in English where as Ukrainian and Russian have the following loan-translations: Ukr. криза середнього віку; Rus. кризис среднего возраста. However, these nominative units are more of terminological (medical) nature as they virtually have no emotivity, expressivity, and intensity. The best example that demonstrates the semantics of midlife crisis the word Torschlusspanik contains, is found in the following discursive excerpt:

(13) Wie alle Mädels des Genres sieht Ute, selbstständig, Single, die Welt strikt manichäisch. Unaufhaltsam nahender Horror: Das 40. Lebensjahr, Zellulitis und Verfall des Frischwerts auf dem Laufsteg der Leiber. Unaufhaltsam entfliehender Traum: Der Märchenprinz. Respektive: jene süsse Mélange aus Macho und Softie, welche man auch als «Halbnackten» Bauarbeiter aus der Limonaden-Reklame kennt. Getrieben von dem, was früher "Torschlusspanik» hiess und heute schlicht «notgeil», fuhrwerkt Ute - Unfall nach Unfall - an der Geschlechterfront herum (DWDS).

This example also contains information that the concept TORSCHLUSSPANIK is being currently replaced by the concept 
NOTGEILHEIT. It is clear that the information is largely subjective. However, the question arises whether the semantic component of 'a fear of being late caused by lack of time' should be considered secondary if its fixation is absent in the 19th century? Of course, it shouldn't. On the contrary, there are some reasons to believe that it is the 'fear of being late' which was the original one (a script of keeping medieval town gates closed at night), and later on the lexeme Torschlusspanik expanded its semantics due to the meaning 'midlife crisis'. A word linguo-specificity is known to change as a result of semantic evolution. Therefore, the lexeme Torschlusspanik reflects both the semantics of such emotional (depressive) state as midlife crisis intensified by another emotion - fear (midlife crisis + fear), and the semantics of fear itself intensified by the emotion of disappointment at being late, not realising smth, failing to do smth etc. (fear + disappointment). In its turn, disappointment is usually accompanied by anger, anxiety, guilt, hostility, malevolence, envy, jealousy, and shame. This means that the analysed word accumulates an emotional «bouquet» which determines its linguo-specificity. The fact that the semantic connotation of the lexeme Torschlusspanik 'a fear of being late caused by lack of time' is often actualized in political discourse, can be simply explained by the way a famous German politician W. Brandt uses the word:

(14) In der auswärtigen Politik sei mit Torschlusspanik nichts gewonnen (Brandt, 1989: 27).

\section{Conclusions}

This article identifies ethno-specific senses of the German linguo-cultural concept TORSCHLUSSPANIK, which represents such a psycho-emotional human state as «midlife crisis», by determining linguo-specificity of the name of the concept. The conducted analysis is based on the methodology, which is a sequence of research procedures and its scientific reliability is provided by Corpus Linguistics data as an empirical basis for linguistic methods proper (etymological, definitional and contextual analyses). Procedure steps of the presented methodology are used to examine cross-language equivalents of the names of concepts in the comparative linguo-cultural studies. Cross-language equivalence allows studying semantic equivalence within the corresponding CWP 
which makes it possible to reveal specific vs. unique senses of the analysed concepts.

The analysis of factual material made it possible to find out that the German ethno-cultural concept TORSCHLUSSPANIK was formed on the basis of historical, cultural and mythological meanings which are still relevant. It is obvious that information about the medieval tradition of keeping town gates closed at night is actualized implicitly in the minds of modern German linguo-culture representatives. The same is true about mythological symbolism of gates within the European linguocultural space because at present (now) it is a person's "middle age» and fears related to it that dominate in the meaning of this concept. To representatives of the Ukrainian language community a symbolic meaning of closing gates as a transition from life to death (gates are closing - life is drawing to an end and it is the time for death) is unfamiliar. For this reason, it makes no sense to keep a form of the transferring German concept unchanged (by means of transcription / transliteration) because the meaning it conveys is not to be found in the Ukrainian CWP. This fragment of the German CWP can be represented (is only possible to represent) in the Ukrainian CWP only by using correlates of the concept TORSCHLUSSPANIK - FEAR, MIDDLE AGE, AGING, TIME, LIFE and DEATH. This way we actualize their symbolic and mythological meanings.

\section{References}

Brandt, W. (1997). Erinnerungen. Berlin: Ullstein.

Brümmer, F. (1913). Lexikon der deutschen Dichter und Prosaisten vom Beginn des 19. Jahrhunderts bis zur Gegenwart. Leipzig: Reclam.

Dalgleich, T., \& Power, M. (Eds.). (1999). Handbook of cognition and emotion. Chichester: Wiley. https://doi.org/10.1002/0470013494

Dobrovol'skij, D. (2006). Zur kontrastiven Analyse kulturspezifischer Konzepte. In U. Breuer \& I. Hyvarinen (Eds.), Wörter - Verbindungen: Festschrift Jarmo Korhonen zum 60. Geburtstag, (pp. 31-45). Frankfurt am Main et al.: Peter Lang.

Dobrovol'skij, D.O. (2015). Korpus parallelnyh tekstov i sopostavitelnaja leksikologija [Parallel Texts Corpus and Contrastive Lexicology]. Trudy instituta russkogo jazyka im. V.V. Vinogradova - The Works of the V.V. Vinogradov Russian Language Institute, 6, 411-446 [in Russian].

Dobrovol'skij, D.O., Kretov, A.A., \& Sharov, S.A. (2005). Korpus parallelnyh tekstov: arhitektura i vozmozhnosti ispolzovanija [Parallel Texts Corpus: Architecture and Possible Use]. Nacional'nyj kopus russkogo jazyka: 2003-2005. Rezul'taty 
The Linguo-Cultural Concept TORSCHLUSSPANIK as the Representative...

$i$ perspektivy - Russian National Linguistic Corpus: 2003-2005. Results and Perspectives (pp. 263-296). Moscow: Indrik [in Russian].

Domasio, A. (2000). Ich fühle also ich bin. Die Entschlüsselung des Bewusstseins. Berlin: List.

DWDS Digitales Wörterbuch der deutschen Sprache. Retrieved from http://www.dwds. de/ressourcen/korpora/

Krumhansl, C.L. (2002). Music: A Link Between Cognition and Emotion. Current Directions in Psychological Science, 11(2), 45-50. https://doi.org/10.1111/14678721.00165

KUM Korpus ukrajins'koji movy [Ukrainian Language Corpus]. Retrieved from http:// www.mova.info/ [in Ukrainian].

Lihachev, D. (1993). Konceptosfera russkogo jazyka [The Conceptsphere of Russian]. Izvestija Akademii Nauk. Serija literatury i jazyka - Bulletin of the Russian Academy of Sciences. Series Literature and Language, 52(1), 3-9 [in Russian].

Mizin, K.I. (2017a). Kontrasty nimeckoho nacionalnoho charaktera: koncepty FERNWEH i HEIMWEH [The Constants of the German National Character: the Concepts FERNWEH and HEIMWEH]. Naukovyj visnyk Mizhnarodnoho humanitarnoho universytetu - International Humanitarian University Herald, 29(2), 67-69 [in Ukrainian].

Mizin, K. (2017b). Lingvokulturnij koncept «Kapci», abo she raz pro metodologichni slabki miscja lingvokul'turologiji [The Linguocultural Concept «Slippers» or Once Again about Methodological Flaws in Linguoculturology]. Movoznavstvo Linguistics, 6, 16-29 [in Ukrainian].

Mizin, K. (2017c). Perspectives for methodological symbiosis of linguo-pragmatics and linguo-conceptology in Ukraine. Acta Fakulty filozofické Západočeské univerzity v Plzni, 9(2), 9-23.

Phelps, E.A. (2006). Emotion and cognition: insights from studies of the human amygdala. Annual review of psychology, 57, 27-53. https://doi.org/10.1146/ annurev.psych.56.091103.070234

Reisenzein, R. (2019). Cognition and emotion: a plea for theory. Cognition and Emotion, 33(1), 109-118. https://doi.org/10.1080/02699931.2019.1568968

Roth, G. (2003). Aus Sicht des Gehirns. Frankfurt am Main: Suhrkamp.

Schwarz, M. (1992). Einführung in die Kognitive Linguistik. Tübingen: Francke.

Schwarz-Friesel, M. (2007). Sprache und Emotion. Tübingen \& Basel: A. Francke Verlag.

Sichinava, D.V. (2014). Ispol'zovanie parallel'nogo korpusa dlja kolichestvennogo izuchenija lingvospecifichnoj leksiki [The Use of Parallel Texts Corpus for Quantitative Study of Vocabulary]. Jazyk, literatura, kul'tura: Aktual'nye problemy izuchenija i prepodavanija - Language, Literature, Culture: Actual Problems of Studying and Teaching, 10, 37-44 [in Russian].

Stepanov, J. (2004). Konstanty: Slovar russkoj kultury [Constants: Vocabulary of Russian Culture]. Moscow: Akademicheskij Proekt [in Russian].

UNLK Ukrajinskyj nacionalnyj lingvistichnyj korpus [Ukrainian National Linguistic Corpus]. Retrieved from http://unlc.icybcluster.org.ua/virt_unlc/ [in Ukrainian].

Zaliznjak, A.A. (2016). Baza dannyh mezhjazykovyh jekvivalencij kak instrument lingvisticheskogo analiza [Data Base of Cross-language Equivalence as an Instrument of Linguistic Analysis]. Kompjuternaja lingvistika $i$ intellektualnye tehnologii - Computational Linguistics and Intellectual Technologies, 15, 840853 [in Russian]. 


\section{АНОТАЦІЯ}

Пропонована стаття присвячена встановленню етноспецифічності німецького лінгвокультурного концепту TORSCHLUSSPANIK, який охоплює широкий смисловий простір психоемоційного світу людини, сконцентрованого навколо смислового центру - «криза середнього віку». Виявлення смислового наповнення цього концепту здійснюється шляхом апробації методики, яка являє собою низку послідовних дослідницьких процедур. Наукова надійність цієї методики забезпечується залученням даних корпусної лінгвістики як емпіричного підсилення для власне лінгвістичних методів. Процедурні кроки опрацьованої методики можуть слугувати для встановлення міжмовних еквівалентів імен концептів у зіставно-лінгвокультурологічних студіях у цілому, оскільки міжмовна еквіваленція виводить дослідження на рівень смислової еквіваленції в межах відповідних когнітивних картин світу (ККС), що уможливлюе встановлення специфічних vs. унікальних смислів зіставлюваних концептів.

Аналіз фоктичного матеріалу виявив, що відтворити той фрагмент німецької KKC, який репрезентує концепт TORSCHLUSSPANIK, в українській ККС можна за допомогою актуалізації смислових корелятів цього концепту СТРАХ, СЕРЕДНІЙ ВІК, СТАРІННЯ, ЧАС, ЖИТТЯ, СМЕРТЬ, активуючИ передусім їхні символічні та -міфологічні смисли. Установлено, що етноспецифічність концепту TORSCHLUSSPANIK виникла внаслідок особливої комбінаторики смислів, що представляють цілу палітру емоційного світу німців, де психоемоційний депресивний стан «криза середнього віку» підсилюється емоцією страху. Остання, у свою чергу, інтенсифікується емоцією досади через запізнення куди-н., нереалізацію чого-н., нездійснення чого-н. тощо. Прикметно, що досада може супроводжуватися при цьому гнівом, тривогою, провиною, ворожістю, злорадістю, заздрістю, ревнивістю, соромом.

Ключові слова: емоція, психоемоційний стан, лінгвокультурний концепт, лінгвокультурологія, середній вік, страх, досада.

\section{Мизин Константин, Летючая Любовь. Лингвокультурный концепт TORSCHLUSSPANIK как репрезентант этноспецифического психоэмоционального состояния немцев}

\section{АННОТАЦИЯ}

Предлагаемая статья посвящена установлению этноспецифичности немецкого лингвокультурного концепта TORSCHLUSSPANIK, который охватывает широкое смысловое пространство психоэмоционального мира человека, сконцентрированного вокруг смыслового центра, - «кризис среднего возраста». Выявление смыслового наполнения этого концепта осуществляется путем апробации методики, которая представляет собой ряд последовательных исследовательских процедур. Научная надежность этой методики обеспечивается привлечением данных корпусной лингвистики как эмпирического усиления для собственно лингвистических методов. Процедурные шаги данной методики могут служить для установления межъязыковых эквивалентов 
The Linguo-Cultural Concept TORSCHLUSSPANIK as the Representative...

имен концептов в сопоставительно-лингвокультурологических студиях в целом, поскольку межъязыковая эквиваленция выводит исследование на уровень смысловой эквиваленции в пределах соответствующих когнитивных картин мира (ККС), что делает возможным установление специфических vs. уникальных смыслов сопоставляемых концептов.

Анализ фактического материала выявил, что воссоздать тот фрагмент немецкой KKC, который представляет концепт TORSCHLUSSPANIK, в украинской ККС можно с помощью актуализации смысловых коррелятов этого концепта СТРАХ, СРЕДНИЙ ВОЗРАСТ, СТАРЕНИЕ, ВРЕМЯ, ЖИЗНЬ, СМЕРТЬ, активирУЯ прежде всего их символические и мифологические смыслы. Установлено, что этноспецифичность концепта TORSCHLUSSPANIK возникла в результате особенной комбинаторики смыслов, которые представляют целую палитру эмоционального мира немцев, где психоэмоциональное депрессивное состояние "кризис среднего возраста» усиливается эмочией страха. Последняя, в свою очередь, интенсифицируется эмоцией досады через опоздание куда-н., нереализацию чего-н., неосуществление чего-н. и т.п. Примечательно, что досада может сопровождаться при этом гневом, тревогой, виной, враждебностью, злорадством, завистью, ревностью, стыдом.

Ключевые слова: эмоция, психоэмочиональное состояние, лингвокультурный концепт, лингвокультурология, средний возраст, страх, досада. 